\title{
Inte riktigt duktig - krasslig på skånska
}

\section{Gunilla Byrman}

\section{Inledning}

År 2002 publicerade jag ett bidrag om adjektivet duktig, och dess bruk och betydelse i skånskt talspråk (Byrman 2002). Bidraget hade sin upprinnelse i en middagskonversation, då en äldre släkting (f. 1912 i Bökesåkra, Skivarp i Skåne) under en familjemiddag i juli 2001 yttrande följande:

(1) Jag känner mig inte riktigt duktig. ('Jag känner mig inte riktigt frisk.')

Av de muntra reaktionerna hos mina döttrar, födda 1983 respektive 1989 i Hardeberga i Lunds kommun, insåg jag att de inte var säkra på vad gammelmoster menade och att de i alla fall inte hade hört uttrycket tidigare. Själv är jag född i mitten av 1900-talet på samma plats som mina döttrar, och i min skånska barndom var uttrycket inte vara duktig ett vanligt sätt att uttrycka att man inte mådde riktigt bra. Att inte vara duktig refererade till sjukdomssymptom av diffus karaktär; det var inte brutna ben eller gallstensanfall, där en säker diagnos kunde ställas, utan det var och är fortfarande frågan om åkommor såsom vag huvudvärk, trötthet, illamående, yrsel eller liknande.

Innan min mosters yttrande om sin hälsa och mina döttrars reaktion på det för dem märkliga ordvalet hade jag inte funderat över att duktig i betydelsen 'frisk, kry' kanske är på väg att försvinna ur skånskan. Detta föranledde mig att studera vad adjektivet duktig betyder och hur ordet konstrueras och används.

\section{Betydelse och etymologi}

I SAOB upptas fem huvudbetydelser och några underbetydelser av ordet duktig. Dessa är följande, något förkortat efter SAOB:

1) som (i sin verksamhet) utmärker sig för (raskhet o.) skicklighet l. kunnighet, som sköter sig bra, (mycket) dugande; flink, "styf"; äfv. i öfverförd anv., om arbetsprodukt (i sht konstverk): skickligt utförd, väl gjord. Det är en mycket duktig karl. En duktig arbetare, konstnär. Vara duktig i skolan. Denne målare har gjort många duktiga saker. En duchtigh prästman och Cappelan (1686). Hon var både duktig att undervisa och styv att hålla ordning (1907).

2) (ngt hvard.) som är en "riktig karl”; behjärtad, modig; i öfverförd anv.: som vittnar om mod l. karlaktighet; numera i sht i fråga om egenskaper som ådagaläggas vid ngt visst tillfälle. Var nu en duktig gosse! Det var duktigt gjordt. Det var duktigt av dig, att du ville kasta dig självmant för vargarna (1907).

3) som är af solid beskaffenhet, bra, förträfflig; numera bl.a. i fråga om storlek 1. mängd 
l. intensitet: "ordentlig”, "riktig”, ”kraftig”, bastant. Han kom hem med ett par duktiga abborrar. Få en duktig skrapa, ett duktigt kok stryk. En duktig regnskur, storm. En duktig summa penningar. Vara duktigt hungrig, trött, varm. Infanteriet gåfwo sina dycktige salvor (1706).

3a) (ngt hvard.) i uttr. duktiga tag, i adverbiell anv.: riktigt ordentligt, starkt, eftertryckligt. Här i Stockholm tjöt vinden duktiga tag kring husknutarna (1912).

3b) (ngt hvard.) ss. n. i substantivisk anv.: riktigt mycket; vanl. i förb. med prep. med. Du måtte fått dugtigt med mat (1885).

4) (ngt hvard.) i fråga om en persons fysiska egenskaper.

4a) om barn: kroppsligt utvecklad, stor, tjock o. fet, "stadig". En duktig flicka (i födelseannons).

4b) robust, klumpig. Hon var en stor, välbygd flicka, för dugtig i sina rörelser att de skulle varit behagliga (1840).

4c) som håller sig fysiskt uppe, frisk, kry; äfv.: som håller stånd (mot angrepp af illamående). Han var litet skraltig i somras, men har nu varit ganska duktig hela hösten (1875).

5) = DUGLIG 2. Duchtigh och Capabel till kiämbnärare (1707). (http://g3.spraakdata.gu.se)

Etymologin av duktig konstrueras på följande sätt i SAOB: [liksom d. dygtig, ä. d. ductig, af nt. dügtig, dugtig, afledn. af mnt. ducht, duktighet, till dogen (se DUGA); jfr holl. duchtig, t. tüchtig. Formen duktig beror möjl. på anslutning till DUGA] (http:// g3.spraakdata.gu.se). Även Elof Hellquist skriver att duktig (omkring 1660) kommer från lågtyskt duchtig med biformen dücktich (varav da. dygtig = ty. tüchtig) (Hellquist 1922:105).

Även i danska finns dygtig belagt i den aktuella betydelsen

2) (nu kun dial.) af sund natur; kraftig; stærk; ogs. m. h. t. helbredstilstand: rask. Beethoven har jeg seet . . Han har sorte Haar, røde Kinder, og seer ret dygtig ud. Men han er meget døv, stakkels Mand! Oehl.Er.III.165. Ing.PO.II.194. Feilb. jf.: *(lægen) priser Charles’ dygtige Natur.Pal M.I.70. † om dyr: kraftig; rask. Den, som . . er indskreven for at kjøre i Reiser, skal for Magistraten beviisliggjøre, at han haver i det ringeste to dygtige Heste. Konfirm.17/121701.§2. (Ordbog over det danske Sprog).

\section{Duktig i skånskt talspråk}

Av SAOB:s betydelser framgår att duktig i betydelsen 4 '(ngt hvard.) i fråga om en persons fysiska egenskaper' ansluter till en av de betydelser ordet kan ha i skånska dialekter. Mest relevant i detta sammanhang är betydelsen under 4c, nämligen 'som håller sig fysiskt uppe, frisk, kry; äfv.: som håller stånd (mot angrepp af illamående)'. Här ser vi att betydelsen 'frisk, kry' finns belagd i skriftspråket, åtminstone under 1800-talet. 
SAOB:s sista skriftliga belägg är från 1892 och artikeln duktig färdigställdes 1922. Exemplet som ges under 4c är:

(2) Han var litet skraltig i somras, men har nu varit ganska duktig hela hösten.

('Han var sjuk i somras, men har nu varit helt frisk hela hösten.' SAOB 1875)

Om vi jämför det med talspråksbelägget från 2001:

(1) Jag känner mig inte riktigt duktig. ('Jag känner mig inte riktigt frisk.'

Björkman 2001)

ser vi att i belägget från SAOB kontrasteras "ganska duktig" mot "litet skraltig" och exempel (1) ovan är negerat. Båda beläggen indikerar att det finns vissa restriktioner på hur duktig i denna betydelse kan konstrueras och användas. Det förefaller som duktig antingen måste stå i ett givet, känt, och mer eller mindre direkt motsatsförhållande till sjukdom, som i belägget från 1875, eller så måste det stå i en negerad sats, som i talspråksbelägget från 2001.

Mina tre informanter fick ta ställning till nedanstående konstruktioner med duktig i betydelsen 'frisk, kry'.

(3) ?Du vet att jag är duktig.

(4) *Jag känner mig duktig.

Den äldsta informanten bedömde (3) som onaturligt och (4) som omöjligt i betydelsen 'frisk, kry' (Björkman 2001). Anledningen till att hon bedömer dem så är förmodligen att meningarna inte är negerade och inte implicerar sjukdom. Även andra medelålders eller äldre personer som är födda och har bott i Skåne hela sitt liv bekräftar att konstruktionerna i (3)-(4) inte är möjliga i den aktualiserade betydelsen. En jämförelse mellan rikssvenska och skånska visar således att det är idiomatiskt rikssvenska att säga: Jag är fullt/helt frisk, men oidiomatiskt att på skånska säga: *Jag är fullt/helt duktig. Det verkar således som duktig i skånskt talspråk och riksspråkligt frisk konstrueras på olika sätt. Orsaken kan vara att duktig här betydelsemässigt närmar sig 'rörlig, handlingskraftig', vilket inte lika självklart ligger i betydelsen frisk, där betydelsefokus snarare är på 'sunt, frånvaro av sjukt’ (jfr Kärrlander 1993:155-157).

Låt oss återvända till meningarna (3)-(4). Om de modifierades med negation eller annat lämpligt adverbial, som gör att sjukdom kan presupponeras utifrån kontexten, så kunde de äldre informanterna godkänna konstruktionerna, som i (4)-(5) nedan:

(5) Du vet att jag inte är duktig. (sjukdom föreligger och det är känt av båda interaktörerna.)

(6) Jag är inte duktig. (= jag är inte frisk, dvs. sjuk.)

(7) Du vet att jag är duktig nu. (det är känt att jag tidigare var sjuk.)

(8) Jag känner mig duktig idag. (men igår var jag sjuk.) 
Själv har jag (f. 1953) samma uppfattning om duktig-konstruktionens acceptans som min äldre släkting, även om jag sällan använder uttrycken aktivt. Men exemplen (5)-(8) är för båda mina döttrar födda på 1980-talet alla konstruktioner omöjliga att använda i vardaglig samspråk med jämnåriga (Byrman \& Byrman 2001).

Det kan finnas flera tänkbara orsaker till att duktig i betydelsen 'frisk, kry' inte finns aktivt i den yngre generationens skånska talspråk. En möjlig orsak till att betydelsen är på väg att försvinna kan vara den nämnda restriktionen i konstruktion och användning som föreligger och som inte finns på adjektivet frisk. En annan tänkbar förklaring kan vara betydelsepåverkan från ordets övriga betydelser, t.ex. 1 i SAOB "som (i sin verksamhet) utmärker sig för (raskhet o.) skicklighet l. kunnighet, som sköter sig bra, (mycket) dugande; flink". Betydelsen här grundar sig på ett värdeomdöme som är diskurskänsligt och inte anses passande att fälla om sig själv, men väl om andra, t.ex.:

(9) Per är en duktig runolog. (duktig 'kunnig, skicklig')

Däremot förekommer ofta i både rikssvenskan och skånskan duktig i negerad sats när någon uttalar sig om sig själv:

(10) Jag är inte duktig i huvudräkning. (duktig 'kunnig, skicklig')

Att det förhåller sig så kan även ha påverkat användningen av duktig i betydelsen 'frisk, kry’. Det vill säga om vi använder ordet duktig om oss själva - oavsett om det betyder 'skicklig, kunnig' eller 'frisk, kry' - så måste det modifieras med ett lämpligt adverbial, i typfallet en negation. Eftersom en person som uppfattas som energisk och duktig av sin omgivning även lätt uppfattas som stolt, högfärdig, kaxig och därmed svårhanterlig (Kärrlander 1993:157) kan en icke-negerad konstruktion med duktig, yttrad av en sådan person, anses opassande då talaren därigenom torgför sina företräden på ett alltför direkt sätt.

I DAL:s samlingar över skånska dialekter fick jag genom en sökning i ordregistret över Skånes alla härader också bekräftat att alla dialektuppteckningar med denna betydelse av duktig har de ovan beskrivna konstruktionsrestriktionerna, som framgår av följande exempel (DAL:s dialektsamlingar. Beläggen skrivs i samlingar med landsmålsalfabetet, men av praktiska skäl återges de här med s.k. grov uttalsbeteckning):

(11) Nu e han dukti ijen. (Nu är han duktig igen. Ö. Vemmenhög härad, Malm, 1921-24)

(12) ... so læenge man va dokti. (... så länge man var duktig. Harjagers härad, Ingers, 1930-31)

(13) So læenge en bara faur va dukti. (Så länge man bara får vara duktig. Torna härad, Ingers, 1944)

(14) Næils e cente dokti enu. (Nils är inte duktig än. Gärds härad, Ingers, 1958) 
Konstruktionerna (11)-(14) ovan har alla ett modifierande adverbial (min kursivering). Om inte dessa funnits där hade betydelsen inte klart framgått och utsagan hade löpt risken att missförstås.

Det visade sig också vid sökningen i DAL:s samlingar att duktig i denna betydelse är belagd i alla härader utom i fyra av de nordligaste. Detta tyder på att betydelsen är förankrad i södra och mellersta Skåne men inte i lika hög grad i norra Skåne, där den enbart finns belagd i Bjäre härad. Duktig i denna betydelse är okänd i småländska dialekter. Sammantaget tyder detta på att uttrycket är företrädesvis syd- och mellanskånskt.

\section{Framtidsprognos}

Adjektivet duktig 'frisk, kry' speglat genom tre generationer av skånska kvinnor visar att ordet i denna betydelse i nuläget är på väg att dö ut i det skånska talspråket. För Anna (f. 1912) ingår betydelse i hennes aktiva ordförråd och för mig (f. 1953) ingår det i mitt passiva ordförråd. Våren 2008 gick min moster ur tiden, och sedan dess har jag tyvärr inte hört detta uttryck användas. Jag känner mig inte riktigt duktig är inget Ylva (f. 1983) eller Astrid (f. 1989) skulle kunna yttra på fullt allvar men väl för att göra sig roliga över äldre generationers språkbruk - ett oortodoxt sätt att föra den halvdöda talspråkliga betydelsen av duktig vidare till nya generationer av talare. Om inte denna metod lyckas - vilket tiden får utvisa - är en inte alltför djärv slutsats att ordet i denna betydelse är på god väg att dö ut i skånskt talspråk.

\section{Källor}

Björkman, A. (2001), Samtal mellan Anna Björkman och Gunilla Byrman, Skatteberga i september 2001.

Byrman, A. (2001), Samtal mellan Astrid Byrman och Gunilla Byrman, Skatteberga i september 2001.

Byrman, Y. (2001), Samtal mellan Ylva Byrman och Gunilla Byrman, Skatteberga i september 2001.

Byrman, G. (2002), ’Duktig - en halvdöd skånsk friskhetsmarkör?”. I Eivindarmál. Heiðursrit til Eivind Weyhe á seksti ára degi hansara 25. apríl 2002. Føroya Fróðskaparfelag. Tórshavn 2002.

DAL, Dialekt- och ortnamnsarkivets i Lund dialektsamlingar över ord i Skånes härader. Hellquist, E. (1922), Svensk etymologisk ordbok. Band 1. Gleerups förlag. Lund: 105.

Kärrlander, E. (1993), Skrabbig och skrallig, karsk och katig. En semantisk studie av svenska dialektala adjektiv avseende hälsotillstånd. Skrifter utgivna genom Dialektoch folkminnesarkivet i Uppsala. Uppsala: 155-157.

Ordbog over det danske Sprog, nätupplagan, adress: http://ordnet.dk/ods/ ordbog?query=dygtig (hämtad 2014-05-12).

SAOB, Svenska Akademiens ordbok (2001). Uppslagsordet duktig i nätversionen av SAOB, adress: http://g3.spraakdata.gu.se 